\title{
Effect of timing of food deprivation on host resistance to fungal infection in mice
}

\author{
Motoko Oarada ${ }^{1}$, Takeshi Nikawa ${ }^{2}$ and Nobuyuki Kurita ${ }^{1}$ \\ ${ }^{1}$ Research Center for Pathogenic Fungi and Microbial Toxicoses, Chiba University, Chiba 260-8673, Japan \\ ${ }^{2}$ Department of Nutrition, Tokushima University School of Medicine, Tokushima 770-8503, Japan
}

(Received 21 May 2001 - Revised 18 February 2002 - Accepted 12 March 2002)

\begin{abstract}
Mice were deprived of food for a period of $72 \mathrm{~h}$ at varying times relative to the time of infection with Paracoccidioides brasiliensis. Host resistance was diminished profoundly when the period of food deprivation was from $48 \mathrm{~h}$ before to $24 \mathrm{~h}$ after infection (group B). When food deprivation was initiated immediately after infection (group C), host resistance was reduced less profoundly. When food deprivation was initiated at 24 and $48 \mathrm{~h}$ post-infection, reductions in host resistance were only moderate or not observed respectively. These results suggest that the earlier in the course of infection starvation occurs, the more profoundly host resistance is impaired. When food deprivation was initiated $72 \mathrm{~h}$ before infection, finishing at the time of infection (group A), the reduction in host resistance was considerably less profound compared with group B mice, suggesting that refeeding initiated immediately after infection is responsible for rapid restoration of the antifungal resistance in starved mice. Infection-induced responses of corticosterone and interferon- $\gamma$ were changed according to the timing of food deprivation. Group A mice, similar to non-fasted controls, showed an infection-induced increase in serum corticosterone concentration, while groups B and C did not. Group C mice showed a substantially greater infection-induced increase in serum interferon- $\gamma$ compared with the other fasted and non-fasted control groups.
\end{abstract}

Acute starvation: Infection: Interferon- $\gamma$ : Corticosterone

It is well known that changes in nutritional state can alter immune responses and influence resistance to infection (Gordon \& Ingalls, 1959; Gross \& Newberne, 1980; Chandra, 1992). In both developing and advanced countries, acute starvation is an important public health problem that occurs in a variety of clinical and social settings. Fasting healthy human subjects for $7 \mathrm{~d}$ decreased peripheral blood mononuclear cell production of interleukin 2 in response to phytohaemagglutinin (Saevendahl \& Underwood, 1997). On the other hand, it was reported that acute starvation increased macrophage activity in mice (Wing et al. 1983). However, the mechanisms underlying the effect of starvation on host resistance still remain to be fully defined.

Paracoccidioides brasiliensis is the causative agent of paracoccidioidomycosis, the most prevalent human systemic mycosis in Latin American countries. Although it has been documented that protection against $P$. brasiliensis in mice is dependent upon cellular immunity (Franco, 1987), there has been no investigation concerning the specific antifungal mechanisms that might be compromised in acute starvation. In an effort to obtain information regarding the mechanisms, we investigated the effect of different timings of $72 \mathrm{~h}$ food deprivation relative to the time of infection on host resistance against $P$. brasiliensis in mice.

\section{Materials and methods}

\section{Fungi}

P. brasiliensis isolate $\mathrm{Pb}-18$, isolated from a Brazilian patient with paracoccidioidomycosis, was employed for infecting mice. Cells of the fungus used in the experiments were newly derived from the mycelial form and subcultured twice at $35^{\circ} \mathrm{C}$ at $4 \mathrm{~d}$ intervals on glucose-supplemented $(10 \mathrm{~g} / \mathrm{l})$ brain-heart infusion (Difco Laboratories, Detroit, MI, USA) agar slants. Fresh growth (4d) of the fungus was collected in sterile saline $(9 \mathrm{~g} / \mathrm{l})$ and passed through a wire mesh to eliminate clumps of fungal cells. After

\footnotetext{
Abbreviations: ACTH, adrenocorticotrophic hormone; CFU, colony-forming units; IFN, interferon.

* Corresponding author: Dr Nobuyuki Kurita, fax +81 43226 2486, email nobu@myco.pf.chiba-u.ac.jp
} 
washing once, fungal cells were counted with a haemocytometer. More than $97 \%$ of the fungal cell units thus prepared were viable (Kurita et al. 1993). Fungal cells were resuspended at desired densities in saline for infecting mice.

\section{Experimental infections}

Specific-pathogen-free 6-week-old female BALB/c mice were obtained from Charles River Japan (Atsugi, Japan), and were maintained at $23^{\circ} \mathrm{C}$ on a $12 \mathrm{~h}$ light-dark cycle (light on 07.00 hours) and allowed free access to standard non-purified MF diet (Oriental Yeast Inc., Osaka, Japan) and water. Mice at the age of 7 weeks were infected by injecting once with $200 \mu \mathrm{l}$ fungal cell suspension (1X $10^{7}$ cells $/ \mathrm{ml}$ ) intravenously via the lateral tail vein at 11.00 hours. Groups of mice were deprived of food for a period of $72 \mathrm{~h}$ at varying times relative to the time of infection as illustrated in Fig. 1. Food deprivation was started at 11.00 hours in all the groups. During the period of food deprivation, mice were allowed free access to water. Mice were killed under diethyl ether anaesthesia at 11.00 hours on days 1-7 post-infection, and blood, spleen and liver were harvested.

The present experiments were performed according to The Guide for the Care and Use of Laboratory Animals (1985) of The National Institute of Health and were approved by The Committee of The Chiba University for Experimental Animals.

\section{Counts of viable fungal cells from organs}

Whole spleens and livers were aseptically removed from mice and homogenized in a glass homogenizer with 4 and $19 \mathrm{ml}$ saline respectively, and samples were diluted with saline. Then, $1 \mathrm{ml}$ of the dilution was plated on brain-heart infusion (Difco Laboratories) agar supplemented with $50 \mu \mathrm{mol}$ EDTA/l, $20 \mathrm{ml}$ horse serum/l (Gibco Laboratories, Grand Island, NY, USA) and

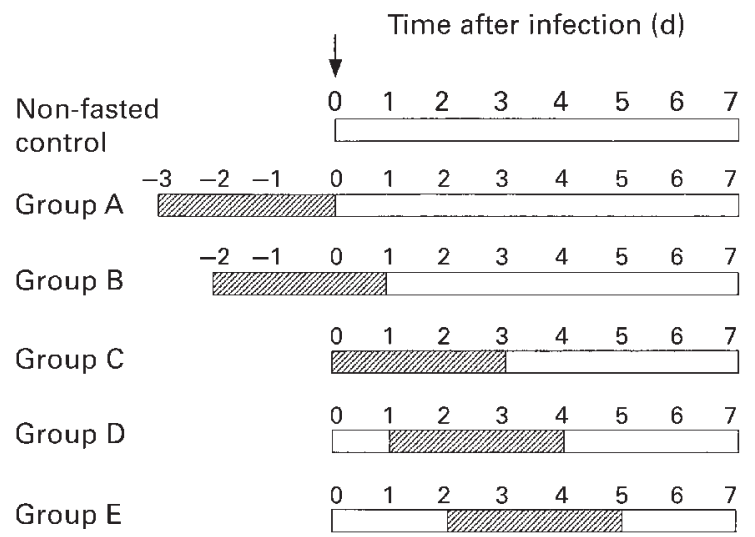

Fig. 1. The experimental protocol of food deprivation and infection Mice were inoculated intravenously with Paracoccidioides brasiliensis $\left(2 \times 10^{6}\right.$ cells/mouse) at 11.00 hours. They were deprived of food for a period of $72 \mathrm{~h}$ at varying times relative to the time of infection. For details of procedures, see p. 152. $\downarrow$, Inoculation with fungai cells ( $P$. brasiliensis, $2 \times 10^{6}$ cells per mouse); Fasting period of $72 \mathrm{~h}$ beginning at 11.00 hours.
$150 \mu \mathrm{mol}$ chloramphenicol/l (Wako Pure Chemical Industries, Osaka, Japan). The agar plates were incubated in a humidified atmosphere at $35^{\circ} \mathrm{C}$, and the colony-forming units (CFU) of $P$. brasiliensis were counted after $12 \mathrm{~d}$ incubation.

\section{Interferon- $\gamma$ assay}

Blood was collected by cardiac puncture and allowed to clot for $40 \mathrm{~min}$ at room temperature. Serum was then separated by centrifugation at $3000 \mathrm{~g}$ for $20 \mathrm{~min}$ at $4^{\circ} \mathrm{C}$. Portions of serum samples were stored at $-80^{\circ} \mathrm{C}$ until interferon (IFN)- $\gamma$ analysis. Spleens and livers were rapidly removed from mice, weighed, placed in cold RPMI 1640 medium, and homogenates $(100 \mathrm{~g} / \mathrm{l})$ were prepared with a glass homogenizer. The homogenates were subjected to two cycles of freeze-thawing, and then were clarified by centrifugation at $9000 \mathrm{~g}$ for $45 \mathrm{~min}$ at $4^{\circ} \mathrm{C}$. The supernatant fractions were assayed for IFN- $\gamma$.

The concentrations of IFN- $y$ in sera and in tissue extracts were determined by an ELISA method using a commercial kit (Amersham International, Amersham, Bucks, UK). Assays were carried out in duplicate and the averages of the individual data were statistically analysed.

\section{Assays of serum corticosterone and adrenocorticotrophic hormone}

Mice were killed by decapitation between 10.30 hours and 11.00 hours on days $1-7$ post-infection and blood was collected. Sera were prepared and stored at $-80^{\circ} \mathrm{C}$ until analysed. Serum corticosterone and adrenocorticotrophic hormone $(\mathrm{ACTH})$ concentrations were determined using a radioimmunoassay kit (ICN Biomedical, Costa Mesa, CA, USA) and an enzyme immunoassay kit (Peninsula Laboratories, Belmont, CA, USA) respectively (Espey \& Basile, 1999). Serum samples were heated to $85^{\circ} \mathrm{C}$ for 15 min prior to analysis of corticosterone to prevent proteolytic interference during radioimmunoassay incubation (Jessop et al. 1987). All assays were carried out in duplicate and the averages of the individual data were statistically analysed.

\section{Statistical analysis}

All data are expressed as mean values with their standard deviations for $n$ observations and statistically evaluated by ANOVA with the SPSS computer programs (release 6.1; SPSS Japan Inc., Tokyo, Japan). Changes in CFU count of $P$. brasiliensis from spleen and liver, and infection-induced changes in IFN- $\gamma$ concentration were evaluated by two-way ANOVA. For corticosterone and ACTH concentrations data, values were analysed by three-way ANOVA. Turkey-HSD tests were used for post-hoc analysis. The level of significance was set at $P<0 \cdot 05$.

\section{Results}

Effect of fasting on antifungal resistance

At the end of the $72 \mathrm{~h}$ food deprivation, body weights of 
Table 1. Recovery of Paracoccidioides brasiliensis from spleens of mice fasted at varying times* (Mean values and standard deviations for five mice per group at each day)

\begin{tabular}{|c|c|c|c|c|c|c|c|c|c|c|c|c|c|c|c|c|}
\hline \multirow[b]{3}{*}{ Group $\ddagger$} & \multicolumn{16}{|c|}{$\%$ CFU at day 0} \\
\hline & \multicolumn{2}{|c|}{$0 \dagger$} & \multicolumn{2}{|c|}{$1 \dagger$} & \multicolumn{2}{|c|}{$2 \dagger$} & \multicolumn{2}{|c|}{$3 \dagger$} & \multicolumn{2}{|c|}{$4 \dagger$} & \multicolumn{2}{|c|}{$5 \dagger$} & \multicolumn{2}{|c|}{$6 \dagger$} & \multicolumn{2}{|c|}{$7 \dagger$} \\
\hline & Mean & SD & Mean & SD & Mean & SD & Mean & SD & Mean & SD & Mean & SD & Mean & SD & Mean & SD \\
\hline Non-fasted control & $100^{d}$ & 6 & $104^{\mathrm{d}}$ & 6 & $84^{\mathrm{de}}$ & 17 & $70^{e}$ & 23 & $46^{\mathrm{ef}}$ & 10 & $28^{f g}$ & 6 & $12^{\mathrm{h}}$ & 6 & $9^{\text {h }}$ & 3 \\
\hline A & $100^{\mathrm{d}}$ & 7 & $102^{d}$ & 12 & $81^{\text {de }}$ & 19 & $91^{\mathrm{de}}$ & 19 & $65^{\mathrm{ef}}$ & 30 & $40^{f}$ & 7 & $21^{\text {gh }}$ & 6 & $21^{\text {gh }}$ & 5 \\
\hline B & $100^{d}$ & 5 & $133^{\mathrm{cd}}$ & 38 & $198^{b}$ & 13 & $275^{a}$ & 8 & $150^{\mathrm{C}}$ & 23 & $108^{\text {cde }}$ & 30 & $55^{\mathrm{ef}}$ & 10 & $43^{\mathrm{ef}}$ & 5 \\
\hline C & $100^{\mathrm{d}}$ & 6 & $97^{\text {de }}$ & 15 & $136^{\mathrm{cd}}$ & 30 & $189^{b c}$ & 54 & $168^{\mathrm{bc}}$ & 47 & $55^{\text {ef }}$ & 20 & $32^{f g}$ & 6 & $26^{9}$ & 3 \\
\hline D & $100^{d}$ & 6 & $118^{d}$ & 12 & $85^{\mathrm{de}}$ & 19 & $85^{\text {de }}$ & 23 & $103^{\text {cde }}$ & 31 & $54^{\text {ef }}$ & 19 & $19^{g h}$ & 6 & $24^{\text {fgh }}$ & 12 \\
\hline $\mathrm{E}$ & $100^{\mathrm{d}}$ & 6 & $107^{d}$ & 6 & $85^{\mathrm{de}}$ & 18 & $61^{e}$ & 6 & $36^{\mathrm{fg}}$ & 9 & $24^{g}$ & 6 & $13^{\mathrm{h}}$ & 6 & $6^{\mathrm{h}}$ & 3 \\
\hline
\end{tabular}

CFU, colony-forming units.

$\mathrm{a}, \mathrm{b}, \mathrm{c}, \mathrm{d}, \mathrm{e}, \mathrm{f}, \mathrm{g}, \mathrm{h}$ Mean values with unlike superscript letters were significantly different $(P<0.05)$.

${ }^{*}$ For details of procedures, see p. 152.

$\dagger$ Time post-infection (d).

$\ddagger$ For details of treatment of each group, see Fig. 1.

the mice in groups $\mathrm{A}, \mathrm{B}, \mathrm{C}, \mathrm{D}$ and $\mathrm{E}$ were reduced to 75.4 , $77.6,78.6,77.3$ and $79.7 \%$ of those at the beginning of food deprivation respectively, and returned to the level of the non-fasted control group after $2-3 \mathrm{~d}$ of refeeding.

The CFU counts recovered from spleen and liver were taken as a measure of the host resistance to infection. The CFU count at day 0 was determined at $2 \mathrm{~h}$ after inoculation. In the non-fasted control group, group A, group D and group E, the spleen CFU count did not vary significantly during the first $2,3,4$ and $2 \mathrm{~d}$ of infection respectively, and thereafter decreased progressively (Table 1). In contrast, in the spleen of groups B and C, the CFU increased, peaking at day 3 post-infection; percentage increase above $\mathrm{CFU}$ at day 0 was greater in group B than group C (275 v. $189 \%$ at day 3$)$. These results indicate that resistance of the spleen is reduced more profoundly in groups $\mathrm{B}$ and $\mathrm{C}$ than group $\mathrm{A}, \mathrm{D}$ or $\mathrm{E}$ and that the reduction is more profound in group $\mathrm{B}$ than group $\mathrm{C}$. In the liver, the CFU count in all the fasted groups and in the non-fasted control group increased, peaking at day 3 or 4 post-infection (Table 2). In group $\mathrm{A}$, the percentage increase in the liver CFU was greater than that of the non-fasted control group (213v.
$136 \%$ at day 4), but smaller than that of group B (213v. $322 \%$ at day 4). Percentage increase in the liver CFU was greater in group B than group C $(359$ v. $255 \%$ at day 3). The increase in CFU count in group $D$ was less than that of group B (230 v. $359 \%$ at day 3$)$. In group E, compared with non-fasted controls, no significant reduction in the host resistance was observed both in the spleen and liver.

\section{Effect of fasting on interferon- $\gamma$ response to infection}

Since IFN- $\gamma$ is a major mediator of host resistance against $P$. brasiliensis infection in mice (Cano et al. 1998), the effect of fasting on the infection-induced IFN- $\gamma$ response was investigated. Group $\mathrm{C}$ mice showed a substantially greater increase in serum IFN- $\gamma$ concentration between day 3 and 4 compared with the non-fasted control group (Table 3). In contrast to group C, in groups A, B, D and $\mathrm{E}$ the overall increase in serum IFN- $\gamma$ concentration (during the first $7 \mathrm{~d}$ of infection) was not markedly different from that of the non-fasted control group.

Group C mice also showed a considerably greater increase in spleen IFN- $\gamma$ concentration between day 3

Table 2. Recovery of Paracoccidioides brasiliensis from livers of mice fasted at varying times* (Mean values and standard deviations for five mice per group at each day)

\begin{tabular}{|c|c|c|c|c|c|c|c|c|c|c|c|c|c|c|c|c|}
\hline \multirow[b]{3}{*}{ Group } & \multicolumn{16}{|c|}{$\%$ CFU at day 0} \\
\hline & \multicolumn{2}{|c|}{$0 †$} & \multicolumn{2}{|c|}{$1 \dagger$} & \multicolumn{2}{|c|}{$2 \dagger$} & \multicolumn{2}{|c|}{$3 \dagger$} & \multicolumn{2}{|c|}{$4 \dagger$} & \multicolumn{2}{|c|}{$5 \dagger$} & \multicolumn{2}{|c|}{$6 \dagger$} & \multicolumn{2}{|c|}{$7 \dagger$} \\
\hline & Mean & SD & Mean & SD & Mean & SD & Mean & SD & Mean & SD & Mean & SD & Mean & SD & Mean & $\mathrm{SD}$ \\
\hline Non-fasted control & $100^{f}$ & 8 & $116^{\text {ef }}$ & 16 & $141^{d}$ & 18 & $222^{\mathrm{bc}}$ & 28 & $136^{d}$ & 8 & $66^{9}$ & 8 & $13^{\mathrm{jk}}$ & 3 & $9^{k}$ & 3 \\
\hline A & $100^{f}$ & 8 & $110^{\mathrm{ef}}$ & 8 & $142^{\mathrm{d}}$ & 15 & $273^{\mathrm{b}}$ & 33 & $213^{c}$ & 25 & $96^{\mathrm{ef}}$ & 21 & $31^{i}$ & 8 & $17^{\mathrm{j}}$ & 4 \\
\hline B & $100^{f}$ & 8 & $139^{\text {de }}$ & 29 & $218^{b c}$ & 58 & $359^{a}$ & 39 & $322^{a b}$ & 43 & $163^{d}$ & 29 & $45^{\mathrm{hi}}$ & 10 & $20^{\mathrm{ij}}$ & 6 \\
\hline C & $100^{f}$ & 8 & $116^{\mathrm{e}}$ & 8 & $161^{\mathrm{d}}$ & 13 & $255^{\mathrm{bc}}$ & 70 & $296^{a b}$ & 41 & $47^{\mathrm{h}}$ & 8 & $27^{i}$ & 6 & $14^{\mathrm{jk}}$ & 3 \\
\hline D & $100^{f}$ & 8 & $100^{f}$ & $\begin{array}{l}0 \\
8\end{array}$ & $142^{\mathrm{d}}$ & 11 & $230^{\mathrm{bc}}$ & 45 & $227^{\text {bcd }}$ & $\begin{array}{l}41 \\
49\end{array}$ & $64^{\mathrm{g}}$ & $\begin{array}{l}0 \\
6\end{array}$ & $19^{\mathrm{ij}}$ & 5 & $13^{\mathrm{jk}}$ & 5 \\
\hline $\mathrm{E}$ & $100^{f}$ & 6 & $111^{\text {ef }}$ & 14 & $142^{d}$ & 12 & $221^{\mathrm{c}}$ & 24 & $145^{d}$ & 15 & $67^{9}$ & 6 & $20^{\mathrm{ij}}$ & 6 & $11^{\mathrm{jk}}$ & 5 \\
\hline
\end{tabular}

CFU, colony-forming units.

$\mathrm{a}, \mathrm{b}, \mathrm{c}, \mathrm{d}, \mathrm{e}, \mathrm{f}, \mathrm{g}, \mathrm{h}, \mathrm{i}, \mathrm{j}, \mathrm{k}$ Mean values with unlike superscript letters were significantly different $(P<0.05)$.

${ }^{*}$ For details of procedures, see p. 152.

†Time post-infection (d).

$\ddagger$ For details of treatment for each group, see Fig 1. 
Table 3. Effect of fasting on serum interferon- $\gamma$ concentration of Paracoccidioides brasiliensis-infected mice*

(Mean values and standard deviations of five mice per group at each day)

\begin{tabular}{|c|c|c|c|c|c|c|c|c|c|c|c|c|c|c|c|c|c|c|c|c|c|c|}
\hline \multirow[b]{3}{*}{ Group $\ddagger$} & \multicolumn{22}{|c|}{$\mathrm{IFN}-\gamma(\mathrm{ng} / \mathrm{ml}$ serum $)$} \\
\hline & \multicolumn{2}{|c|}{$-3 \dagger$} & \multicolumn{2}{|c|}{$-2 \dagger$} & \multicolumn{2}{|c|}{$-1 \dagger$} & \multicolumn{2}{|c|}{$0 \dagger$} & \multicolumn{2}{|c|}{$1 \dagger$} & \multicolumn{2}{|c|}{$2 \dagger$} & \multicolumn{2}{|c|}{$3+$} & \multicolumn{2}{|c|}{$4 \dagger$} & \multicolumn{2}{|c|}{$5 \dagger$} & \multicolumn{2}{|c|}{$6 \dagger$} & \multicolumn{2}{|c|}{$7 \dagger$} \\
\hline & Mean & $\overline{S D}$ & Mean & SD & Mean & SD & Mean & SD & Mean & SD & Mean & SD & Mean & SD & Mean & SD & Mean & SD & Mean & SD & Mean & SD \\
\hline $\begin{array}{l}\text { Non- } \\
\text { fasted } \\
\text { control }\end{array}$ & un & & un & & un & & un & & un & & $0 \cdot 18^{\mathrm{de}}$ & 0.13 & $0.38^{\text {cde }}$ & 0.20 & $1 \cdot 70^{\mathrm{b}}$ & 0.41 & $0.64^{\mathrm{cd}}$ & 0.33 & $0.15^{\mathrm{e}}$ & $0 \cdot 10$ & ur & \\
\hline A & un & & un & & un & & un & & un & & \multicolumn{2}{|c|}{$u^{f}{ }^{f}$} & $0.50^{\mathrm{cd}}$ & 0.20 & $0.86^{c}$ & 0.29 & $1 \cdot 23^{b c}$ & 0.45 & $0.28^{\text {de }}$ & 0.08 & $0.08^{\text {ef }}$ & 0.06 \\
\hline B & - & & un & & un & & un & & un & & \multicolumn{2}{|c|}{$u^{f}{ }^{\dagger}$} & $0.53^{\mathrm{c}}$ & 0.15 & $1 \cdot 16^{\mathrm{bc}}$ & 0.23 & $1 \cdot 18^{\mathrm{bc}}$ & 0.11 & $0.48^{\mathrm{C}}$ & $0 \cdot 10$ & $0.06^{\mathrm{ef}}$ & 0.05 \\
\hline C & - & & - & & - & & un & & un & & $0.14^{\text {def }}$ & 0.12 & $1.67^{\mathrm{b}}$ & 0.65 & $4 \cdot 00^{\mathrm{a}}$ & 0.43 & $1.65^{\mathrm{bc}}$ & 0.63 & $0.29^{\text {de }}$ & 0.08 & $0.19^{\text {de }}$ & 0.06 \\
\hline D & - & & - & & - & & un & & un & & $0.31^{d}$ & 0.08 & $1.02^{\mathrm{bc}}$ & 0.40 & $1 \cdot 13^{\mathrm{bc}}$ & 0.33 & $1 \cdot 29^{b c}$ & 0.30 & $0.44^{\mathrm{cd}}$ & 0.20 & $0.14^{\mathrm{e}}$ & 0.08 \\
\hline$E$ & - & & - & & - & & un & & un & & $0 \cdot 18^{\mathrm{de}}$ & 0.12 & $1 \cdot 21^{\mathrm{bc}}$ & 0.43 & $1 \cdot 36^{\mathrm{bc}}$ & 0.17 & $0.80^{c}$ & 0.16 & $0.93^{\mathrm{C}}$ & 0.42 & $0.07^{\text {ef }}$ & 0.08 \\
\hline
\end{tabular}

IFN, interferon; un, $<0.05 \mathrm{ng} / \mathrm{ml}$ serum.

$\mathrm{a}, \mathrm{b}, \mathrm{c}, \mathrm{d}, \mathrm{e}, \mathrm{f}$ Mean values with unlike superscript letters were significantly different $(P<0.05)$.

*For details of procedures, see p. 152.

$\dagger$ Time post-infection(d).
†For details of treatment of each group, see Fig. 1.

Table 4. Effect of fasting on spleen interferon- $\gamma$ concentration of Paracoccidioides brasiliensis-infected mice*

(Mean values and standard deviations for five mice per group at each day)

\begin{tabular}{|c|c|c|c|c|c|c|c|c|c|c|c|c|c|c|c|c|c|c|c|c|c|c|}
\hline \multirow[b]{3}{*}{ Group $\ddagger$} & \multicolumn{22}{|c|}{ IFN- $\gamma$ (ng/g organ) } \\
\hline & \multicolumn{2}{|c|}{$-3 \dagger$} & \multicolumn{2}{|c|}{$-2 \dagger$} & \multicolumn{2}{|c|}{$-1 \dagger$} & \multicolumn{2}{|c|}{$0 \dagger$} & \multicolumn{2}{|c|}{$1 \dagger$} & \multicolumn{2}{|c|}{$2 \dagger$} & \multicolumn{2}{|c|}{$3 \dagger$} & \multicolumn{2}{|c|}{$4 \dagger$} & \multicolumn{2}{|c|}{$5 \dagger$} & \multicolumn{2}{|c|}{$6 \dagger$} & \multicolumn{2}{|c|}{$7 \dagger$} \\
\hline & Mean & SD & Mean & SD & Mean & SD & Mean & SD & Mean & SD & Mean & SD & Mean & SD & Mean & SD & Mean & SD & Mean & SD & Mean & SD \\
\hline $\begin{array}{l}\text { Non- } \\
\text { fasted } \\
\text { control }\end{array}$ & un & & ur & & un & & un & & $0.60^{f}$ & 0.10 & $0.71^{f}$ & 0.18 & $2 \cdot 36^{c}$ & 0.23 & $2 \cdot 41^{b c}$ & 0.38 & $2 \cdot 06^{\mathrm{bcd}}$ & 0.75 & $0.96^{\text {ef }}$ & 0.23 & $0.60^{f}$ & 0.14 \\
\hline A & un & & ur & & un & & un & & $0.74^{f}$ & 0.08 & $0.98^{\mathrm{ef}}$ & 0.15 & $1.99^{\mathrm{C}}$ & 0.30 & $2 \cdot 70^{\mathrm{bc}}$ & 0.75 & $3.05^{\mathrm{b}}$ & 0.40 & $1.45^{d}$ & 0.23 & $1.00^{\mathrm{e}}$ & 0.13 \\
\hline B & - & & ur & & un & & un & & $0.63^{f}$ & 0.06 & $0.55^{f}$ & 0.12 & $2 \cdot 73^{\mathrm{bc}}$ & 0.60 & $2.99^{\mathrm{b}}$ & 0.20 & $2.98^{\mathrm{b}}$ & 0.13 & $1.05^{\mathrm{e}}$ & 0.20 & $0.65^{f}$ & 0.15 \\
\hline C & - & & - & & - & & un & & $0.57^{f}$ & 0.11 & $0.75^{\dagger}$ & 0.13 & $3.71^{\mathrm{ab}}$ & 1.00 & $6 \cdot 16^{a}$ & 2.35 & $5 \cdot 41^{\mathrm{a}}$ & 1.20 & $1.40^{\mathrm{d}}$ & 0.16 & $0.61^{f}$ & 0.18 \\
\hline D & - & & - & & - & & un & & $0.63^{f}$ & 0.11 & $0.80^{\text {ef }}$ & 0.15 & $2 \cdot 41^{\mathrm{c}}$ & 0.31 & $2 \cdot 43^{\mathrm{C}}$ & 0.22 & $2 \cdot 35^{\mathrm{bc}}$ & 0.45 & $1.02^{\mathrm{de}}$ & 0.30 & $0.70^{f}$ & 0.13 \\
\hline$E$ & - & & - & & - & & un & & $0.61^{f}$ & 0.09 & $0.78^{\text {ef }}$ & 0.13 & $2 \cdot 68^{\mathrm{bc}}$ & 0.28 & $2 \cdot 54^{b c}$ & 0.39 & $2 \cdot 10^{C}$ & 0.32 & $1.23^{\mathrm{de}}$ & 0.42 & $0.65^{f}$ & 0.14 \\
\hline
\end{tabular}

IFN, interferon; un, $<0.47 \mathrm{ng} / \mathrm{g}$ organ.

作

*For details of procedures, see p. 152.

$\ddagger$ For details of treatment of each group, see Fig. 1 . 
and 5 compared with the non-fasted control group (Table 4).

In the liver, IFN- $\gamma$ constitutively existed at a concentration of $3 \cdot 2-4 \cdot 8 \mathrm{ng} / \mathrm{g}$ wet tissue. In all groups, including the non-fasted control group, the liver IFN- $\gamma$ concentration increased to $7 \cdot 8-9.5 \mathrm{ng} / \mathrm{g}$ wet tissue by day 3 after infection, stayed at an elevated concentration until day 5, and then returned to the basal concentration by day 7 (results not shown).

\section{Effect of fasting on corticosterone and adrenocorticotrophic hormone responses during infection}

Glucocorticoids have been well documented to be involved in suppression of inflammation and immune reactions (Munck et al. 1984). It is well known that treatment with glucocorticoids increases vulnerability to infections. The serum glucocorticoid concentration is known to increase in response to various factors, including fasting (Millward et al. 1983; Mitev et al. 1993) and infections (Zhang et al. 1998). In all the fasted groups, the serum corticosterone concentration increased due to the $72 \mathrm{~h}$ fasting process (Table 5), and returned to the pre-fasting level within $1 \mathrm{~h}$ after initiation of refeeding (results not shown). In group A mice, like non-fasted controls, the serum corticosterone concentration increased in response to infection, peaking at day 4 post-infection. In contrast, an infection-induced increase in the serum corticosterone did not occur in groups $\mathrm{B}$ and $\mathrm{C}$. In groups $\mathrm{D}$ and $\mathrm{E}$, day 4 of infection overlapped the fasting period. In these groups, the infected mice did not show a greater increase in serum corticosterone concentration compared with non-infected mice.

Table 6 shows variation of the serum ACTH concentration in response to fasting and infection. Mice in all the fasted groups had an increased serum ACTH concentration during the $72 \mathrm{~h}$ fasting period. The fastinginduced increase in ACTH concentration was reversed within $1 \mathrm{~h}$ of initiation of refeeding (results not shown). Non-fasted control mice showed an infection-induced increase in the serum ACTH concentration $(1.50 \mathrm{ng} / \mathrm{ml}$ serum at day 5 post-infection), while groups $\mathrm{A}, \mathrm{B}, \mathrm{C}$ and $\mathrm{D}$ did not. In group $\mathrm{E}$, day 5 of infection overlapped the fasting period. In this group, the infected mice did not show a greater increase in serum ACTH concentration compared with non-infected mice.

\section{Discussion}

The present study revealed that difference in timing of starvation and refeeding relative to the time of infection is responsible for a substantial variation in host resistance. Fasted mice in group $\mathrm{C}$ showed greater spleen IFN- $\gamma$ production (Table 4) and higher serum IFN- $\gamma$ concentrations (Table 3) in response to infection compared with the non-fasted control group, while their host resistance was reduced (Tables 1 and 2). The reason for the greater IFN- $\gamma$ production in group $\mathrm{C}$ mice is unclear. It has been reported that overproduction of IFN- $\gamma$ is responsible for increased lethality of Candida albicans-infected mice (Lavigne et al. 1998), and that treatment with anti-IFN- $\gamma$ antibody improves the survival of mice infected with gram-negative bacteria (Kohler et al. 1993). Thus, the greater IFN- $\gamma$ response of group $\mathrm{C}$ mice could be more detrimental to the host compared with the case of the non-fasted control group, although it might simultaneously contribute to host resistance against $P$. brasiliensis. It is well known that the rate of biosynthesis and/or release of various hormones and neuropeptides vary rapidly in response to starvation and refeeding. Beer et al. (1989) have reported that, in human subjects, plasma cortisol, ACTH, $\beta$-endorphin and adrenaline concentrations increase, and plasma insulin concentration decreases, within $9 \mathrm{~h}$ after initiation of $72 \mathrm{~h}$ starvation, returning to or near pre-starvation concentration within $6 \mathrm{~h}$ after initiation of refeeding. Millward et al. (1983) have shown in rats that change in plasma corticosterone and insulin concentrations due to $4 \mathrm{~d}$ food deprivation return to the prefasting level within as little as 40 and $180 \mathrm{~min}$ of initiation of refeeding respectively. On the other hand, it has been well documented that various hormones and neuropeptides, as well as cytokines, are able to influence immunological activities and also host resistance (Blalock, 1989). Thus, it is assumed that variation in host resistance due to different timings of acute starvation (and refeeding) is, at least partly, associated with rapid changes in the rate of synthesis and release of certain hormones and/or neuropeptides. Group A mice, in which $72 \mathrm{~h}$ starvation was finished at the time of infection and refeeding was initiated immediately after infection, showed a less profound reduction in host resistance compared with group $\mathrm{B}$, in which infection was initiated at $48 \mathrm{~h}$ time point of $72 \mathrm{~h}$ starvation (Tables 1 and 2 ). In group A mice, serum corticosterone and ACTH concentrations returned rapidly to the pre-fasting levels within $1 \mathrm{~h}$ of infection due to refeeding, which commenced at the same time as infection. This may, at least partly, account for the only moderate reduction in host resistance of these mice. In group $B$, the last $24 \mathrm{~h}$ of the $72 \mathrm{~h}$ fasting period overlapped the first $24 \mathrm{~h}$ of infection (Fig. 1). Thus, increased serum corticosterone and ACTH concentrations persisted throughout the first $24 \mathrm{~h}$ of infection (Tables 5 and 6). Group $\mathrm{C}$ mice showed a less profound reduction in host resistance than group $\mathrm{B}$ mice. In group $\mathrm{C}$ mice, the serum corticosterone and $\mathrm{ACTH}$ concentrations were as low as those of the non-fasted control group during the first $4-6 \mathrm{~h}$ of infection (results not shown). The different pattern in corticosterone and ACTH concentrations during the initial stage of infection between groups B and C may, at least partly, account for the more profound reduction in host resistance in the former than the latter group (Tables 1 and 2). Group $\mathrm{E}$ mice, in which the fasting was initiated $48 \mathrm{~h}$ after infection, showed no significant reduction in host resistance compared with the non-fasted control group. Taken together, our results suggest that if infection occurs during a period of elevation of glucocorticoid concentration due to starvation, then host resistance is profoundly impaired. Since starvation and refeeding could influence responses of not only glucocorticoids and ACTH but also other hormones and neuropeptides (Millward et al. 1983; Beer et al. 1989), the mechanisms underlying the variation in host resistance due to different timings of acute starvation remain to be further investigated. 
Table 5. Effect of fasting on serum corticosterone concentration of Paracoccidiodes brasiliensis-infected mice* (Mean values and standard deviations for five mice per group at each day)

\begin{tabular}{|c|c|c|c|c|c|c|c|c|c|c|c|c|c|c|c|c|c|c|c|c|c|}
\hline \multirow[b]{3}{*}{ Group $\ddagger$} & \multirow[b]{3}{*}{ Infection§ } & \multicolumn{20}{|c|}{ Corticosterone (ng/ml serum) } \\
\hline & & \multicolumn{2}{|c|}{$-3 \dagger$} & \multicolumn{2}{|c|}{$-2 \dagger$} & \multicolumn{2}{|c|}{$-1 \dagger$} & \multicolumn{2}{|c|}{$0+$} & \multicolumn{2}{|c|}{$1 \dagger$} & \multicolumn{2}{|c|}{$2 \dagger$} & \multicolumn{2}{|c|}{$3+$} & \multicolumn{2}{|c|}{$4 \dagger$} & \multicolumn{2}{|c|}{$5 \dagger$} & \multicolumn{2}{|c|}{$7 \dagger$} \\
\hline & & Mean & SD & Mean & $\mathrm{SD}$ & Mean & $\mathrm{SD}$ & Mean & SD & Mean & SD & Mean & SD & Mean & SD & Mean & SD & Mean & SD & Mean & SD \\
\hline $\begin{array}{l}\text { Non- } \\
\text { fasted } \\
\text { control }\end{array}$ & - & $65^{\mathrm{de}}$ & 12 & $68^{\mathrm{de}}$ & 13 & $64^{\text {def }}$ & 15 & $68^{\mathrm{de}}$ & 12 & $45^{f}$ & 10 & $43^{\text {efg }}$ & 14 & $45^{\text {efg }}$ & 15 & $50^{\text {ef }}$ & 8 & $50^{\text {def }}$ & 15 & $60^{\text {def }}$ & 20 \\
\hline $\begin{array}{l}\text { Non- } \\
\text { fasted } \\
\text { control }\end{array}$ & + & - & & - & & - & & - & & $122^{\mathrm{C}}$ & 30 & $202^{\mathrm{bc}}$ & 59 & $258^{\mathrm{b}}$ & 69 & $402^{a b}$ & 125 & $288^{a b}$ & 109 & $192^{\mathrm{bc}}$ & 62 \\
\hline $\begin{array}{l}\text { A } \\
\text { A }\end{array}$ & $\begin{array}{l}- \\
+\end{array}$ & ${ }_{-}^{65^{\mathrm{de}}}$ & 10 & $351^{\mathrm{ab}}$ & 154 & $4^{430^{\mathrm{ab}}}$ & 125 & $\frac{506^{\mathrm{a}}}{-}$ & 143 & $\begin{array}{l}60^{\text {def }} \\
62^{\mathrm{e}}\end{array}$ & $\begin{array}{r}15 \\
8\end{array}$ & $\begin{array}{l}60^{\text {ef }} \\
73^{\text {cdef }}\end{array}$ & $\begin{array}{l}10 \\
39\end{array}$ & $\begin{array}{l}57^{\text {def }} \\
83^{\text {cdefg }}\end{array}$ & $\begin{array}{l}18 \\
57\end{array}$ & $\begin{array}{c}65^{\text {def }} \\
433^{a}\end{array}$ & $\begin{array}{r}22 \\
115\end{array}$ & $\begin{array}{c}80^{\text {cde }} \\
238^{\mathrm{b}}\end{array}$ & $\begin{array}{l}25 \\
87\end{array}$ & $\begin{array}{c}95^{\text {cde }} \\
138^{\text {bcde }}\end{array}$ & $\begin{array}{l}35 \\
71\end{array}$ \\
\hline B & - & - & & $58^{\text {ef }}$ & 13 & $342^{\mathrm{ab}}$ & 135 & $422^{\mathrm{a}}$ & 110 & $379^{\mathrm{ab}}$ & 150 & $71^{\text {de }}$ & 15 & $63^{\text {def }}$ & 17 & $21^{g}$ & 14 & $86^{\text {cdef }}$ & 40 & $105^{\mathrm{cd}}$ & 25 \\
\hline B & + & - & & - & & - & & - & & $474^{a}$ & 127 & $93^{\mathrm{cd}}$ & 13 & $58^{\text {def }}$ & 25 & $48^{\text {ef }}$ & 16 & $49^{\text {defg }}$ & 30 & $60^{\text {defg }}$ & 35 \\
\hline C & - & - & & - & & - & & $67^{\mathrm{de}}$ & 14 & $351^{\mathrm{ab}}$ & 120 & $447^{\mathrm{a}}$ & 127 & $457^{\mathrm{a}}$ & 99 & $51^{\text {ef }}$ & 12 & $50^{\text {ef }}$ & 10 & $80^{d}$ & 10 \\
\hline C & + & - & & - & & - & & - & & $368^{a b}$ & 125 & $389^{a b}$ & 122 & $448^{a}$ & 112 & $50^{\text {ef }}$ & 16 & $53^{\text {ef }}$ & 15 & $48^{\text {ef }}$ & 9 \\
\hline $\mathrm{D}$ & - & - & & - & & - & & $69^{\mathrm{de}}$ & 11 & $52^{\mathrm{ef}}$ & 12 & $345^{\mathrm{ab}}$ & 117 & $435^{a}$ & 114 & $417^{\mathrm{ab}}$ & 133 & $52^{\text {ef }}$ & 10 & $60^{\text {ef }}$ & 10 \\
\hline D & + & - & & - & & - & & - & & $98^{\mathrm{cd}}$ & 25 & $360^{\mathrm{ab}}$ & 132 & $442^{\mathrm{ab}}$ & 133 & $438^{\mathrm{ab}}$ & 128 & $51^{\text {ef }}$ & 13 & $53^{\text {ef }}$ & 11 \\
\hline $\mathrm{E}$ & - & - & & - & & - & & $68^{\mathrm{de}}$ & 14 & $51^{\text {ef }}$ & 9 & $50^{\text {ef }}$ & 13 & $358^{\mathrm{ab}}$ & 132 & $433^{a}$ & 120 & $420^{\mathrm{ab}}$ & 125 & $50^{\text {ef }}$ & 12 \\
\hline $\mathrm{E}$ & + & - & & - & & - & & - & & $101^{c d}$ & 22 & $168^{\mathrm{bc}}$ & 48 & $371^{\mathrm{ab}}$ & 140 & $419^{a b}$ & 118 & $435^{\mathrm{ab}}$ & 134 & $48^{\text {ef }}$ & 15 \\
\hline
\end{tabular}

a,b,c,d,e,f,g Mean values with unlike superscript letters were significantly different $(P<0.05)$.

*For details of procedures, see p. 152.

$\dagger$ Time post-infection (d).

(a) 1.

$\S$ Mice were injected with saline with $(+)$ or without $(-)$ fungal cells at day 0 (for details see p. 152). 
Table 6. Effect of fasting on serum adrenocorticotrophic hormone concentration of Paracoccidioides brasiliensis-infected mice* (Mean values and standard deviations for five mice per group at each day)

\begin{tabular}{|c|c|c|c|c|c|c|c|c|c|c|c|c|c|c|c|c|c|c|c|c|c|}
\hline \multirow[b]{3}{*}{ Group $\ddagger$} & \multirow[b]{3}{*}{ Infection§ } & \multicolumn{20}{|c|}{ ACTH $(\mathrm{ng} / \mathrm{ml}$ serum) } \\
\hline & & \multicolumn{2}{|c|}{$-3 \dagger$} & \multicolumn{2}{|c|}{$-2 \dagger$} & \multicolumn{2}{|c|}{$-1 \dagger$} & \multicolumn{2}{|c|}{$0 \dagger$} & \multicolumn{2}{|c|}{$1 \dagger$} & \multicolumn{2}{|c|}{$2 \dagger$} & \multicolumn{2}{|c|}{$3 \dagger$} & \multicolumn{2}{|c|}{$4 \dagger$} & \multicolumn{2}{|c|}{$5 \dagger$} & \multicolumn{2}{|c|}{$7 \dagger$} \\
\hline & & Mean & SD & Mean & SD & Mean & SD & Mean & SD & Mean & SD & Mean & SD & Mean & SD & Mean & SD & Mean & SD & Mean & SD \\
\hline $\begin{array}{l}\text { Non- } \\
\text { fasted } \\
\text { control }\end{array}$ & - & $0.52^{\mathrm{e}}$ & 0.09 & $0.57^{\mathrm{de}}$ & $0 \cdot 11$ & $0.54^{\mathrm{e}}$ & 0.09 & $0.52^{\mathrm{e}}$ & 0.09 & $0.94^{\mathrm{bc}}$ & 0.14 & $0.87^{c d}$ & 0.20 & $0.73^{\mathrm{cd}}$ & $0 \cdot 12$ & $0.76^{\mathrm{cd}}$ & 0.08 & $0.81^{c d}$ & 0.14 & $0.81^{\mathrm{cd}}$ & 0.13 \\
\hline $\begin{array}{l}\text { Non- } \\
\text { fasted } \\
\text { control }\end{array}$ & + & - & & - & & - & & - & & $1.07^{\mathrm{bc}}$ & 0.10 & $0.77^{\mathrm{cd}}$ & 0.05 & $0.73^{\mathrm{cd}}$ & $0 \cdot 11$ & $0.92^{\mathrm{cd}}$ & 0.15 & $1.50^{\mathrm{a}}$ & 0.07 & $0.85^{\mathrm{cd}}$ & 0.18 \\
\hline A & - & $0.48^{\mathrm{e}}$ & 0.12 & $1.33^{\mathrm{abc}}$ & 0.35 & $1 \cdot 25^{\mathrm{abc}}$ & 0.36 & $1 \cdot 19^{\mathrm{abc}}$ & 0.28 & $0.53^{\mathrm{de}}$ & 0.12 & $0.53^{\mathrm{e}}$ & $0 \cdot 10$ & $0.59^{\mathrm{de}}$ & $0 \cdot 15$ & $0.63^{\text {de }}$ & 0.14 & $0.73^{\text {cde }}$ & 0.17 & $0.71^{d}$ & 0.10 \\
\hline$A$ & + & - & & - & & - & & - & & $0.57^{\mathrm{de}}$ & 0.13 & $0.57^{\mathrm{de}}$ & 0.11 & $0.87^{\mathrm{bcd}}$ & 0.23 & $0.72^{\text {cd }}$ & $0 \cdot 16$ & $0.85^{\text {cd }}$ & 0.11 & $0.93^{\mathrm{bcd}}$ & 0.17 \\
\hline B & - & - & & $0.51^{\mathrm{e}}$ & 0.11 & $1.41^{\mathrm{abc}}$ & 0.43 & $1 \cdot 19^{\mathrm{bc}}$ & 0.19 & $1.11^{\mathrm{bc}}$ & 0.24 & $0.48^{\mathrm{e}}$ & 0.08 & $0.50^{\mathrm{e}}$ & 0.13 & $0.49^{\mathrm{e}}$ & 0.09 & $0.58^{\mathrm{de}}$ & 0.15 & $0.61^{\text {de }}$ & 0.12 \\
\hline B & + & - & & - & & - & & - & & $0.93^{\mathrm{c}}$ & 0.13 & $0.47^{e}$ & 0.08 & $0.48^{\mathrm{e}}$ & 0.13 & $0.48^{\mathrm{e}}$ & 0.12 & $0.78^{\text {cd }}$ & 0.15 & $0.70^{\text {cde }}$ & 0.20 \\
\hline C & - & - & & - & & - & & $0.50^{e}$ & 0.10 & $1.30^{\mathrm{ab}}$ & 0.21 & $1 \cdot 19^{b}$ & 0.13 & $1 \cdot 21^{\mathrm{b}}$ & 0.12 & $0.51^{\mathrm{e}}$ & 0.07 & $0.53^{\mathrm{e}}$ & 0.10 & $0.51^{\mathrm{e}}$ & 0.09 \\
\hline C & + & - & & - & & - & & - & & $1.32^{\mathrm{ab}}$ & 0.18 & $1 \cdot 23^{\mathrm{b}}$ & 0.19 & $1.17^{\mathrm{b}}$ & 0.12 & $0.48^{\mathrm{e}}$ & 0.08 & $0.52^{\mathrm{e}}$ & 0.08 & $0.54^{\mathrm{de}}$ & 0.11 \\
\hline $\mathrm{D}$ & - & - & & - & & - & & $0.51^{e}$ & $0 \cdot 10$ & $0.85^{\mathrm{cd}}$ & 0.14 & $1.29^{a b c}$ & 0.28 & $1.25^{\mathrm{abc}}$ & 0.40 & $1 \cdot 12^{\mathrm{bc}}$ & 0.18 & $0.54^{\mathrm{de}}$ & 0.20 & $0.48^{\mathrm{de}}$ & 0.13 \\
\hline D & + & - & & - & & - & & - & & $0.93^{\mathrm{c}}$ & 0.14 & $1.30^{\mathrm{ab}}$ & 0.25 & $1.24^{\mathrm{abc}}$ & 0.37 & $1.11^{\mathrm{bc}}$ & 0.25 & $0.59^{\mathrm{de}}$ & 0.14 & $0.53^{\mathrm{de}}$ & 0.11 \\
\hline $\mathrm{E}$ & - & - & & - & & - & & $0.50^{\mathrm{e}}$ & 0.11 & $0.89^{\text {cd }}$ & 0.16 & $0.73^{\mathrm{cd}}$ & 0.13 & $1 \cdot 28^{\mathrm{abc}}$ & 0.42 & $1 \cdot 26^{\mathrm{abc}}$ & 0.30 & $1.19^{\mathrm{abc}}$ & 0.41 & $0.51^{\mathrm{e}}$ & 0.12 \\
\hline $\mathrm{E}$ & + & - & & - & & - & & - & & $0.89^{\mathrm{C}}$ & 0.11 & $0.72^{\mathrm{cd}}$ & 0.14 & $1 \cdot 30^{a b c}$ & 0.38 & $1.25^{\mathrm{abc}}$ & 0.39 & $1.25^{\mathrm{abc}}$ & 0.35 & $0.52^{\mathrm{de}}$ & 0.14 \\
\hline
\end{tabular}

ACTH, adrenocorticotrophic hormone.

a,b,c,d,e Mean values within a column with unlike superscript letters were significantly different $(P<0.05)$.

${ }^{*}$ For details of procedures, see p. 152.

†Time post-infection (d).

$\ddagger$ For details of treatment of each group, see Fig. 1.

$\S$ Mice were injected with saline with $(+)$ or without $(-)$ fungal cells at day 0 (for details see p. 152). 


\section{Acknowledgements}

This work was supported in part by grants-in-aid for Scientific Research from The Skylark Food Science Foundation (to M.O. and N.K.).

\section{References}

Beer SF, Bircham PMM, Bloom SR, Clark PM, Hales CN, Hughes CM, Jones CT, Marsh DR, Raggatt PR \& Findlay ALR (1989) The effect of a 72-h fast on plasma levels of pituitary, adrenal, thyroid, pancreatic and gastrointestinal hormones in healthy men and women. Journal of Endocrinology 120, $337-350$.

Blalock JE (1989) A molecular basis for bidirectional communication between the immune and neuroendocrine systems. Physiological Reviews 69, 1-32.

Cano LE, Kashino SS, Arruda C, Andre D, Xidieh CF, SingerVermes LM, Vaz CA, Burger E \& Calich VL (1998) Protective role of gamma interferon in experimental pulmonary paracoccidioidomycosis. Infection and Immunity 66, 800-806.

Chandra RK (1992) Protein-energy malnutrition and immunological responses. Journal of Nutrition 122, 597-600.

Espey MG \& Basile AS (1999) Glutamate augments retrovirusinduced immunodeficiency through chronic stimulation of the hypothalamic-pituitary-adrenal axis. Journal of Immunology 162, 4998-5002.

Franco M (1987) Host-parasite relationship in paracoccidioidomycosis. Journal of Medical and Veterinary Mycology 25, $5-18$.

Gordon JE \& Ingalls TH (1959) Preventive medicine and epidemiology. American Journal of Medical Sciences 237, 367-403.

Gross RL \& Newberne PM (1980) Role of nutrition in immunologic function. Physiological Reviews 60, 188-302.

Jessop DS, Patience RL, Cunnah D \& Rees LH (1987) The use of reversed-phase high-performance liquid chromatography to detect proteolytic activity from human pancreas in a radioimmunoassay for corticotrophin-releasing factor. Journal of Endocrinology 114, 147-151.

Kohler J, Heumann D, Garotta G, LeRoy D, Bailat S, Barras C, Baumgartner JD \& Glauser MP (1993) IFN- $\gamma$ involvement in the severity of gram-negative infections in mice. Journal of Immunology 151, 916-921.

Kurita N, Sano A, Coelho KRI, Takeo K, Nishimura K \& Miyaji M (1993) An improved culture medium for detecting live yeast phase cells of Paracoccidioides brasiliensis. Journal of Medical and Veterinary Mycology 31, 201-205.

Lavigne LM, Schopf LR, Chung CL, Maylor R \& Sypek JP (1998) The role of recombinant murine IL-12 and IFN- $\gamma$ in the pathogenesis of a murine systemic Candida albicans infection. Journal of Immunology 160, 284-292.

Millward DJ, Odera B \& Bates PC (1983) The role of insulin, corticosterone and other factors in the acute recovery of muscle protein synthesis on refeeding food deprived rats. Biochemical Journal 216, 583-587.

Mitev Y, Almeida OFX \& Patchev V (1993) Pituitary-adrenal function and hypothalamic beta-endorphin release in vitro following food deprivation. Brain Research Bulletin 30, 7-10.

Munck A, Guyre PM \& Holbrook NJ (1984) Physiological functions of glucocorticoids in stress and their relation to pharmacological action. Endocrine Reviews 5, 25-44.

Saevendahl L \& Underwood LE (1997) Decreased interleukin-2 production from cultured peripheral blood mononuclear cells in human acute starvation. Journal of Clinical Endocrinology and Metabolism 82, 1177-1180.

Wing EJ, Barczynski LK \& Boehmer SM (1983) Effect of acute nutritional deprivation on immune function in mice. Immunology 48, 543-550.

Zhang D, Kishihara K, Wang B, Mizobe K, Kubo C \& Nomoto K (1998) Restraint stress-induced immunosuppression by inhibiting leukocyte migration and Th1 cytokine expression during the intraperitoneal infection of Listeria monocytogenes. Journal of Neuroimmunology 92, 139-151. 